\title{
Why I Asked the Editors of Criminology to Retract Johnson, Stewart, Pickett, and Gertz (2011)
}

\author{
Justin T. Pickett \\ School of Criminal Justice \\ University at Albany, SUNY
}

\begin{abstract}
My coauthors and I were informed about data irregularities in Johnson, Stewart, Pickett, and Gertz (2011), and in my coauthors' other articles. Subsequently, I examined my limited files and found evidence that we: 1) included hundreds of duplicates, 2) underreported the number of counties, and 3) somehow added another 316 respondents right before publication (and over a year after the survey was conducted) without changing nearly any of the reported statistics (means, standard deviations, regression coefficients). The survey company confirmed that it sent us only 500 respondents, not the 1,184 reported in the article. I obtained and reanalyzed those data. This report presents the findings from my reanalysis, which suggest that the sample was not just duplicated. The data were also altered — intentionally or unintentionally — in other ways, and those alterations produced the article's main findings. Additionally, we misreported data characteristics as well as aspects of our analysis and findings, and we failed to report the use of imputation for missing data. The following eight findings emerged from my reanalysis:
\end{abstract}

1) The article reports 1,184 respondents, but actually there are 500 .

2) The article reports 91 counties, but actually there are 326.

3) The article describes respondents that differ substantially from those in the data.

4) The article reports two significant interaction effects, but actually there are none.

5) The article reports the effect of Hispanic growth is significant and positive, but actually it is non-significant and negative.

6) The article reports many other findings that do not exist in the data.

7) The standard errors are stable in our published article, but not in the actual data or in articles published by other authors using similar modeling techniques with large samples.

8) Although never mentioned in the article, 208 of the 500 respondents in the data (or $42 \%$ ) have imputed values.

*Direct correspondence to Justin T. Pickett, School of Criminal Justice, University at Albany, SUNY, 135 Western Avenue, Albany, NY 12222 e-mail (jpickett@albany.edu). 


\section{BACKGROUND}

On May 5, 2019, my coauthors and I received an email that identified data irregularities in our study, Johnson, Stewart, Pickett, and Gertz (2011), and in four other articles by my coauthors. I asked my coauthors to send me the full data for Johnson et al. (2011), but encountered difficulties getting them. Consequently, I examined the limited files I already had, and discovered 500 unique respondents and 500 duplicates, as well as several other problems, like inexplicable changes in sample size from manuscript draft $(N=868)$ to published article $(N$ $=1,184)$ that did not affect means, standard deviations, or regression coefficients. I sent an email to my coauthors on June 6 that listed these issues and provided my files (see Appendix A). One of my coauthors, Dr. Gertz, then contacted the former director of the Research Network, who confirmed that the survey he ran for us included only 500 respondents. At that point, Dr. Stewart sent me a copy of the data for our article $(N=500)$.

In the article, we claim to have 1,184 respondents nested in 91 counties. In the actual data, there are only 500 respondents, and they are nested in 326 counties. Dr. Stewart acknowledged that both the sample size and county number reported in the article were wrong. He said the explanations for the differences were that: 1) he accidently doubled the sample, and 2) he created 91 "county clusters" for the analysis by grouping together the 326 counties. The published article never mentions county clusters, or grouping together counties. It is also unclear how the sample of 500 grew to 1,184 in our article, and then to 1,379 in Dr. Stewart's later Social Problems article (Stewart et al., 2015), which uses the same data (with the same 54.8\% response rate, and same $\$ 62,700$ mean family income). Duplicating the 500 respondents, as Dr. Stewart said he did, would lead to a sample size of only 1,000. 
I should note that my coauthors are working on an erratum. Dr. Stewart now says there were two surveys conducted for our study, one with 500 respondents and one with 425 , and that the results for the combined sample $(N=925)$ are similar to those in the published article. However, I am uncomfortable with the new results for four reasons. First, I have not seen them. Dr. Stewart has not sent me the data for the second sample, and although he has sent Stata output for the combined sample to the lead author, Dr. Johnson, he has asked him not to share it. Second, the published article reports 1,184 respondents, not 925. Third, our published article lists only one survey company — the Research Network—and one survey. Fourth, Dr. Stewart has refused to tell me who conducted the second survey, and Dr. Johnson has said he does not know who conducted it. This lack of transparency and accountability is why I have decided not to wait for my coauthors to finish their reanalysis before asking for a retraction.

Before I discovered the duplicates in our data, Dr. Stewart had never mentioned a second survey or any survey company besides the Research Network. The email I have from the Research Network says it conducted one survey for Dr. Stewart $(N=500)$, sent that data to him in January 2008, and then, at his request, sent the county identifiers for 420 of those same respondents to him in May 2008. It did not conduct a second survey. Therefore, the remainder of this report focuses on the findings from my reanalysis of the data I can account for $(N=500)$, which are from the sample that our article describes (albeit inaccurately) and that Dr. Stewart initially said he doubled accidently. I did ask Dr. Stewart for the full sample (with duplicates included) of 1,184 respondents that he initially said he used in his original analysis for our article. Unfortunately, he doesn't have it, because he saved over it after dropping the duplicates. 


\section{REANALYSIS FINDINGS}

The evidence suggests the data were altered in ways besides duplication. The descriptive statistics in the published article should match those in the data, even if the 500 respondents were accidently doubled. Doubling the sample would increase the sample size, but it would not change its composition. However, the descriptive statistics in the published article differ substantially from the actual data. The outcome variable in our analysis is public support for the use of defendants' ethnicity in sentencing decisions. The distribution of the outcome variable by respondents' race is shown in Figure 1 of the published article (Johnson et al., 2011: 419). Here is how it compares to the actual data:

\section{Figure 1. Published Article Vs. Actual Data}

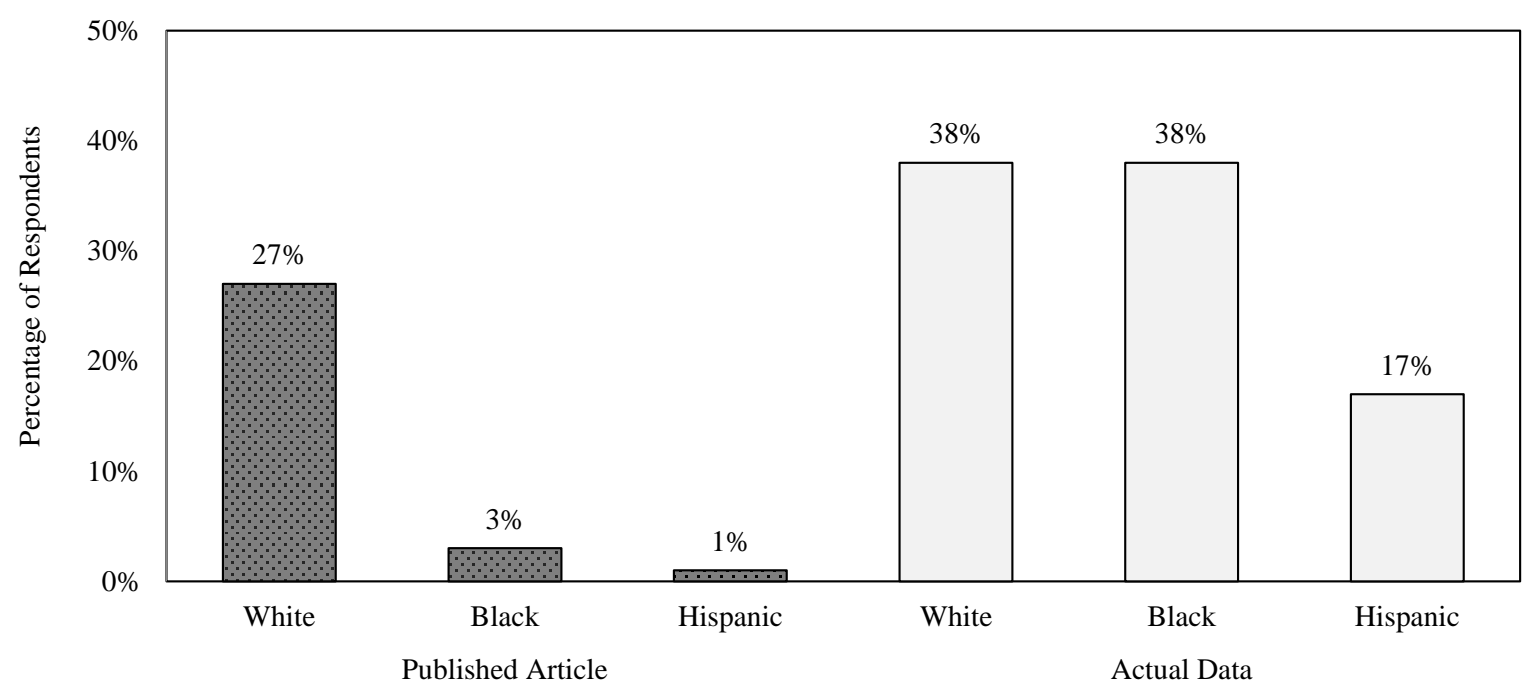

Doubling the sample and then adding another 184 respondents (to get the reported sample size of 1,184 ) cannot explain these discrepancies. For example, even adding 184 Black respondents who ALL oppose ethnicity-based sentencing would reduce the percent of Blacks supporting it from $38 \%$ to $13 \%$, not to the article's $3 \%$. And this is not the only noteworthy 
distributional difference. The table below compares all of the descriptive statistics in the published article to those in the actual data.

Table 1. Descriptive Statistics: Published Article vs. Actual Data

\begin{tabular}{|c|c|c|c|c|c|}
\hline \multirow[b]{2}{*}{ Variables } & \multicolumn{2}{|c|}{ Published Article } & \multicolumn{2}{|c|}{ Actual Data } & \multirow{2}{*}{$\begin{array}{l}p \text {-value for } \\
\text { Difference }\end{array}$} \\
\hline & Mean & SD & Mean & SD & \\
\hline Use of ethnicity in punishment & .31 & .46 & .37 & 48 & .007 \\
\hline Hispanic criminal threat & 4.93 & 1.66 & 2.85 & 2.67 & .000 \\
\hline Hispanic economic threat & 1.72 & 1.13 & 1.64 & 1.13 & .137 \\
\hline Hispanic political threat & 4.38 & 1.41 & 1.95 & 1.59 & .000 \\
\hline Percent Hispanic & .12 & .11 & 9.52 & 11.61 & .000 \\
\hline Hispanic growth & .26 & 1.53 & 3.18 & 3.11 & .000 \\
\hline Homicide rate (per 100,000 ) & 3.96 & 4.37 & 3.92 & 4.25 & .819 \\
\hline Concentrated disadvantage & 1.09 & 1.53 & 1.40 & .94 & .000 \\
\hline Percent Republican & 53.04 & 13.02 & 52.56 & 13.07 & .415 \\
\hline Percent Black & .10 & .14 & 11.63 & 11.98 & .000 \\
\hline Population structure & 5.39 & .70 & 5.11 & 1.00 & .000 \\
\hline White & .86 & .41 & .85 & .36 & .606 \\
\hline Black & .10 & .33 & .10 & .30 & 1.000 \\
\hline Hispanic & .04 & .22 & .05 & .21 & .494 \\
\hline Age & 47.12 & 19.72 & 46.41 & 16.98 & .352 \\
\hline Male & .47 & .50 & .46 & .50 & .591 \\
\hline Married & .59 & .31 & .61 & .49 & 275 \\
\hline Education level (college graduate) & .42 & .31 & .42 & .49 & 902 \\
\hline Family income & $\$ 62,700$ & $\$ 14,210$ & $\$ 61,196$ & $\$ 22,593$ & 137 \\
\hline Employed & .46 & .50 & .55 & .50 & .000 \\
\hline Political conservative & .43 & .31 & .70 & .46 & .000 \\
\hline Own home & .78 & .33 & .78 & .41 & .829 \\
\hline Southwest & .17 & .41 & .16 & .37 & .721 \\
\hline Northeast & .15 & .35 & .15 & .36 & .802 \\
\hline Midwest & .24 & .43 & .24 & .43 & 917 \\
\hline West & .17 & .38 & .17 & .38 & .812 \\
\hline South & .44 & .39 & .43 & .50 & .787 \\
\hline General punitive attitudes & 6.84 & 2.16 & 4.69 & 3.57 & .000 \\
\hline
\end{tabular}

The means for 11 of the 28 variables (or 39\%) differ significantly between the article and data. For example, the published article claims that $43 \%$ of respondents are political conservatives. In the actual data, $70 \%$ are political conservatives. Again, even doubling the sample to 1,000, and then adding 184 liberals, would only drop the percentage of conservatives in the sample to $59 \%$, not to the $43 \%$ reported in the article. Similarly, the mean for Hispanic 
criminal threat is almost two points higher (mean $=4.93$ vs. 2.85$)$, and the mean for general punitive attitudes is over two points higher (mean $=6.84$ vs. 4.69$)$, in the published article than in the actual data. Even doubling the sample and then adding 184 respondents with the highest possible value (a value of 9) on these two variables would only increase their means to 3.81 and 5.36, respectively; both still a point lower than in the article.

Accidently doubling the sample of 500 respondents would leave the regression coefficients unscathed - they would be identical if all respondents were duplicated. However, the regression results in the published article differ substantially from those in the actual data. Most notably, the main findings in the article - the interaction effect of perceived Hispanic threat (criminal and economic) and Hispanic growth—do not emerge with the actual data. Those findings are reported in Table 3 of Johnson et al. (2011: 423). In the actual data, none of the coefficients for the interaction terms are statistically significant and they are all much smaller. This is shown in the table below.

Table 2. Interaction Effects: Published Article vs. Actual Data

\begin{tabular}{|c|c|c|c|c|c|c|}
\hline \multirow[b]{2}{*}{ Variables } & \multicolumn{3}{|c|}{ Published Article } & \multicolumn{3}{|c|}{ Actual Data } \\
\hline & $b$ & $\mathrm{SE}$ & $\operatorname{Exp}(b)$ & $b$ & SE & $\operatorname{Exp}(b)$ \\
\hline Variables & - & - & - & - & - & - \\
\hline Perceived Hispanic threat & 一 & - & - & - & - & - \\
\hline Criminal threat & $.183^{*}$ & .079 & 1.201 & $.212 * * *$ & .048 & 1.236 \\
\hline Economic threat & $.272 *$ & .111 & 1.312 & $.632 * * *$ & .124 & 1.881 \\
\hline Political threat & .008 & .116 & 1.009 & -.045 & .072 & .956 \\
\hline Aggregate Hispanic threat & - & - & - & - & - & - \\
\hline Percent Hispanic & -.089 & .766 & .815 & $.032 *$ & .015 & 1.032 \\
\hline Hispanic growth & $.334 * *$ & .127 & 1.396 & -.121 & .064 & .886 \\
\hline Interactions & - & - & - & - & - & - \\
\hline Criminal * His. Growth & $.126^{*}$ & .051 & 1.134 & .026 & .017 & 1.026 \\
\hline Economic * His. Growth & $.175^{*}$ & .073 & 1.191 & .015 & .055 & 1.015 \\
\hline Political * His. Growth & -.101 & .087 & .904 & .007 & .022 & 1.007 \\
\hline Intercept & $-.848 * * *$ & .119 & - & $-.776 * * *$ & .121 & - \\
\hline
\end{tabular}

$* \mathrm{p}<.05 ; * * \mathrm{p}<.01 ; * * * \mathrm{p}<.001$ (two-tailed). 
The main effect of Hispanic growth also fails to replicate in the actual data; indeed, the coefficient is in the opposite direction. This is the case even when the interaction terms are removed from the model. In the published article, the main effect of Hispanic growth is shown Model 2 of Table 2, and is positive and highly statistically significant $(b=.288, p<.01)$. In the actual data, the coefficient is negative and non-significant. The table below compares the estimates in Johnson et al. (2011: 420) to those from the actual data. The differences are striking, extending to many other variables besides Hispanic growth. For example, the coefficient for Black in the published article is negative and significant $(b=-.628, p<.05)$, but it is positive and significant in the actual data $(b=.949, p<.01)$.

Table 3. Model 2 in Published Article vs. Actual Data

\begin{tabular}{|c|c|c|c|c|c|c|}
\hline \multirow[b]{2}{*}{ Variables } & \multicolumn{3}{|c|}{ Published Article } & \multicolumn{3}{|c|}{ Actual Data } \\
\hline & $b$ & SE & $\operatorname{Exp}(b)$ & $b$ & SE & $\operatorname{Exp}(b)$ \\
\hline Percent Hispanic & -.104 & .662 & .901 & .021 & .020 & 1.021 \\
\hline Hispanic growth & $.288 * *$ & .102 & 1.334 & -.070 & .053 & .933 \\
\hline Homicide rate (per 100,000 ) & -.013 & .033 & .987 & -.031 & .030 & .970 \\
\hline Concentrated disadvantage & .051 & .086 & 1.052 & .033 & .144 & 1.034 \\
\hline Percent Republican & .001 & .005 & 1.000 & .009 & .009 & 1.009 \\
\hline Percent Black & -.038 & .173 & .963 & .003 & .012 & 1.003 \\
\hline Population structure & -.051 & .174 & .950 & .068 & .126 & 1.070 \\
\hline Black & $-.628 *$ & .248 & .534 & $.949 * *$ & .361 & 2.582 \\
\hline Hispanic & $-.982 * *$ & .359 & .375 & -.752 & .547 & .472 \\
\hline Age & $.016 * *$ & .005 & .016 & .004 & .006 & 1.004 \\
\hline Male & $.164 * *$ & .056 & 1.178 & -.111 & .199 & .895 \\
\hline Married & .208 & .201 & 1.231 & $.425^{*}$ & .210 & 1.529 \\
\hline Education level & -.099 & .198 & .906 & .215 & .226 & 1.240 \\
\hline Family income & -.026 & .061 & .974 & .062 & .096 & 1.064 \\
\hline Employed & $-.191^{*}$ & .082 & .826 & -.058 & .202 & .944 \\
\hline Political conservative & $.367^{*}$ & .146 & 1.443 & .360 & .218 & 1.434 \\
\hline Own home & -.137 & .246 & .872 & .158 & .281 & 1.171 \\
\hline Southwest & -.111 & .274 & .895 & .721 & .369 & 2.057 \\
\hline Northeast & -.183 & .281 & .832 & .522 & .334 & 1.686 \\
\hline Midwest & .054 & .230 & 1.055 & .102 & .291 & 1.107 \\
\hline West & .082 & .264 & 1.085 & -.350 & .362 & .705 \\
\hline General punitive attitudes & $.191 * *$ & .062 & 1.210 & $.175^{* * *}$ & .031 & 1.191 \\
\hline Intercept & $-.858 * * *$ & .105 & - & $-.640 * * *$ & .097 & - \\
\hline
\end{tabular}

$* \mathrm{p}<.05 ; * * \mathrm{p}<.01 ; * * * \mathrm{p}<.001$ (two-tailed). 
There are other issues with the data that are concerning. For example, one of the irregularities raised in the email we received was the high degree of stability in standard errors across the three models in Table 2 of our published article (Johnson et al., 2011: 420-421). In the article, 21 regressors are included in all three models and 19 of them (or 90\%) have standard errors that are perfectly stable. In the actual data, not a single regressor has a standard error that is stable across the models. As the table below shows, this is the case regardless of whether the models are estimated using logistic regression (with clustered standard errors) or multilevel modeling. In the table, there are boxes around the stable standard errors.

Table 4. Standard-Error Stability: Published Article vs. Actual Data

\begin{tabular}{|c|c|c|c|c|c|c|c|c|c|}
\hline \multirow[b]{2}{*}{ Variables } & \multicolumn{3}{|c|}{ Published Article } & \multicolumn{3}{|c|}{ Actual Data: Logistic } & \multicolumn{3}{|c|}{ Actual Data: Multilevel } \\
\hline & $\begin{array}{c}\text { Model 1: } \\
\text { SE }\end{array}$ & $\begin{array}{c}\text { Model 2: } \\
\text { SE }\end{array}$ & $\begin{array}{c}\text { Model 3: } \\
\text { SE }\end{array}$ & $\begin{array}{l}\text { Model 1: } \\
\text { SE }\end{array}$ & $\begin{array}{c}\text { Model 2: } \\
\text { SE }\end{array}$ & $\begin{array}{c}\text { Model 3: } \\
\text { SE }\end{array}$ & $\begin{array}{c}\text { Model 1: } \\
\text { SE }\end{array}$ & $\begin{array}{c}\text { Model 2: } \\
\text { SE }\end{array}$ & $\begin{array}{c}\text { Model 3: } \\
\text { SE }\end{array}$ \\
\hline Criminal threat & - & - & .084 & - & - & .048 & - & - & .049 \\
\hline Economic threat & - & - & .111 & - & - & .121 & - & - & .117 \\
\hline Political threat & - & - & .107 & - & - & .073 & - & - & .073 \\
\hline Percent Hispanic & - & .662 & .669 & - & .020 & .016 & - & .018 & .019 \\
\hline Hispanic growth & 一 & .102 & .101 & - & .053 & .053 & - & .057 & .064 \\
\hline Homicide rate & .033 & .033 & .033 & .030 & .030 & .029 & .028 & .028 & .031 \\
\hline Concentrated dis. & .086 & .086 & .086 & .134 & .144 & .148 & .129 & .146 & .158 \\
\hline Percent Repub. & .005 & .005 & .005 & .009 & .009 & .011 & .010 & .010 & .011 \\
\hline Percent Black & .173 & .173 & .173 & .012 & .012 & .013 & .012 & .013 & .014 \\
\hline Population structure & .173 & .174 & .185 & .119 & .126 & .141 & .118 & .125 & .144 \\
\hline Black & .248 & .248 & .248 & .359 & .361 & .389 & .364 & .365 & .411 \\
\hline Hispanic & .359 & .359 & .359 & .540 & .547 & .518 & .604 & .607 & .666 \\
\hline Age & .005 & .005 & .005 & .006 & .006 & .007 & .006 & .006 & .007 \\
\hline Male & .056 & .056 & .056 & .200 & .199 & .227 & .202 & .204 & .228 \\
\hline Married & .201 & .201 & .201 & .206 & .210 & .266 & .226 & .228 & .255 \\
\hline Education level & .198 & .198 & .198 & .225 & .226 & .247 & .218 & .218 & .243 \\
\hline Family income & .061 & .061 & .061 & .096 & .096 & .104 & .096 & .097 & .108 \\
\hline Employed & .082 & .082 & .082 & .201 & .202 & .228 & .213 & .214 & .237 \\
\hline Political conservative & .146 & .146 & .146 & .217 & .218 & .260 & .228 & .229 & .264 \\
\hline Own home & .246 & .246 & .246 & .277 & .281 & .313 & .278 & .279 & .316 \\
\hline Southwest & .274 & .274 & .274 & .287 & .369 & .369 & .310 & .377 & .425 \\
\hline Northeast & .281 & .281 & .281 & .327 & .334 & .384 & .341 & .348 & .387 \\
\hline Midwest & .230 & .230 & .230 & .287 & .291 & .332 & .293 & .300 & .333 \\
\hline West & .264 & .264 & .264 & .360 & .362 & .379 & .366 & .369 & .413 \\
\hline General punitive & .062 & .062 & .062 & .031 & .031 & .035 & .033 & .033 & .036 \\
\hline Intercept & .102 & .105 & .119 & .097 & .097 & .116 & .101 & .102 & .117 \\
\hline
\end{tabular}

NOTES: Stable standard errors are boxed in. 
The observed differences in standard-error stability between our published article and the actual data are so startling that I searched for other articles to compare. I found several published by other prominent scholars in top journals that, in design and analysis, are comparable to ours. Specifically, they all have large samples, include a series of multilevel regression models examining one outcome variable (stepwise, building from a baseline model), and report standard errors to the third decimal place:

$>$ Hagan, Shedd, and Payne (2005), American Sociological Review

$>$ Kirk (2008), Demography

$>$ Kirk and Matsuda (2011), Criminology

$>$ Sampson, Morenoff, and Raudenbush (2005), American Journal of Public Health

$>$ Slocum, Taylor, Brick, and Esbensen (2010), Criminology

$>$ Xie, Lauritsen, and Heimer (2012), Criminology

I have included the relevant regression tables from all of these articles in Appendix B of this report. None of the articles exhibit the degree of standard-error stability we report in Johnson et al. (2011). Instead, they all are consistent with the actual data we have, and show that standard errors normally vary across stepwise multilevel models, the main exception being standard errors with two leading zeros (e.g., SE = .005).

Another issue with our data is item missing values. In the file Dr. Stewart sent me, all 500 respondents have complete data on every variable. In most surveys, a substantial number of respondents have missing values on some of the variables (e.g., income). Closer inspection of the data reveals that mean imputation was used to impute missing values for 208 respondents (or $42 \%$ of the sample). This is problematic because in our published article we never mention imputation, much less inform readers that we used mean imputation specifically. Dropping cases with imputed values results in findings that look even less like those reported in the published 
article (e.g., the negative coefficient for Hispanic growth becomes larger and statistically significant $[b=-.202, \mathrm{p}=.028]$, opposite the article's positive and significant coefficient).

\section{CONCLUSION}

There is only one possible conclusion from reanalyzing the data I have: the sample was not just duplicated in the analysis for the published article; the data were also altered, whether intentionally or unintentionally, and those alterations produced the article's main findings. It may be that appending the data I have and the data Dr. Stewart has for the second sample of 425 respondents would change this conclusion. Unfortunately, the data for the second survey are not forthcoming; neither is an answer about who conducted that survey. Regardless, our published article did not report a second survey, or a sample of 925; it reported one survey of 1,184 respondents by the Research Network.

Three other things are incontrovertible. First, we omitted important information that must be reported to journal referees and readers, like the use of imputation for item missing data. Second, we misreported data characteristics, like the number of counties-there were at least 326 counties, not 91 . Third, if Dr. Stewart grouped counties into "county clusters," then we consistently misreported our measurement of variables, analysis, and findings (emphasis added): "we matched respondents to the 91 counties where they resided to assess objective measures of aggregate threat characteristics ... as well as county-level controls" (pp. 412); "model 1 of table 2 provides baseline estimates for the effects of county and demographic controls on the dependent variable" (p. 418); "we also estimated a series of interactions between Hispanic population growth and county-level controls" (p. 423); "both criminal and economic ethnic threat measures became stronger as the Hispanic growth rate increased in the county" (p. 428). It is also unclear 
how exactly Dr. Stewart grouped the counties. He has not provided the code for generating county clusters or any cluster-level data. ${ }^{1}$

My coauthors are working on an erratum, and Dr. Stewart's reanalysis is ongoing.

However, given 1) the number and severity of the data discrepancies, 2) the lack of transparency about the second sample, which was not reported in the published article, and 3) the misreporting of data characteristics, methodology, and findings, I believe we should retract our study altogether. I have asked the editors of Criminology to do so.

\footnotetext{
${ }^{1}$ There seems to be little reason to use county clusters in our study. It is not desirable to group together counties, because it throws away geographic detail and creates "meaningless socio-political entities" (Hagen et al., 2013: 770). Typically, researchers only group together counties in historical studies that examine data over a large number of decades or across centuries, and even in those studies they only create county clusters for those specific counties that have boundaries that changed during the time period examined (e.g., King et al., 2009; Messner et al., 2005).
} 


\section{REFERENCES}

Hagan, John, Carla Shedd, and Monique R. Payne. 2005. Race, ethnicity, and youth perceptions of criminal injustice. American Sociological Review 70: 381-407.

Hagen, Ryan, Kinga Makovi, and Peter Bearman. 2013. The influence of political dynamics on southern lynch mob formation and lethality. Social Forces 92: 757-787.

Johnson, Brian D., Eric A. Stewart, Justin Pickett, and Marc Gertz. 2011. Ethnic threat and social control: Examining public support for judicial use of ethnicity in punishment. Criminology 49: 401-441.

King, Ryan D., Steven F. Messner, and Robert D. Baller. 2009. Contemporary hate crimes, law enforcement, and the legacy of racial violence. American Sociological Review 74: 291315.

Kirk, David S. 2008. The neighborhood context of racial and ethnic disparities in arrest. Demography 45: 55-77.

Kirk, David S., and Mauri Matsuda. 2011. Legal cynicism, collective efficacy, and the ecology of arrest. Criminology 49: 443-472.

Messner, Steven F., Robert D. Baller, and Matthew P. Zevenbergen. 2005. The legacy of lynching and southern homicide. American Sociological Review 70: 633-655.

Sampson, Robert J., Jeffrey D. Morenoff, and Stephen Raudenbush. 2005. Social anatomy of racial and ethnic disparities in violence. American Journal of Public Health 95: 224-232.

Slocum, Lee A., Terrance J. Taylor, Bradley T. Brick, and Finn-Aage Esbensen. 2010. Neighborhood structural characteristics, individual-level attitudes, and youths' crime reporting intentions. Criminology 48: 1063-1100.

Stewart, Eric A., Ramiro Martinez, Jr., Eric P. Baumer, and Marc Gertz. (2015) The social context of latino threat and punitive Latino sentiment. Social Problems 62: 69-92.

Xie, Min, Janet L. Lauritsen, and Karen Heimer. 2012. Intimate partner violence in U.S. metropolitan areas: The contextual influences of police and social services. Criminology 50: 961-992. 


\section{APPENDIX A: "FILES AND CONCERNS" EMAIL}

Brian, Eric and Marc,

I have spent the day going back through all of my records for our 2011 Criminology article. I located files and emails that, without additional data, I have difficulty attributing to any benign explanation.

Here is the background: the data for our 2011 paper were collected in early 2008, and the paper was written in 2009. In fall 2009, after the analysis was finished and the paper was written, we sent it out for feedback from colleagues. One of them suggested that we control for county political climate. In response, Eric sent me a limited version of the data, so that I could add in county voting percentages. I was a graduate student at the time. I have attached the limited data Eric sent me (justin_voting_data.xls), as well as the data I sent back (Voting - Data.xls). Three things concern me.

The first, and the one that worries me the least, is that there are 1,000 respondents in the data, not 1,184 as we say in the published article. Eric sent me this data in December 2009, the same month we sent the manuscript to Criminology. Therefore, the sample size should match what we report in the article.

What is more concerning is that half of these 1,000 respondents are duplicates. That is, the data include two exact copies of the same 500 respondents. If you open the data set and sort on "case," you can see that cases 501 to 1,000 are exact copies of cases 1 to 500. To make it easier to see, I have included another excel sheet (Case_comparison.xls) with these cases placed next to each other. This suggests someone may have copied and pasted the rows in the original data, and then given them new case numbers (501 to 1,000).

Just as concerning, the 500 unique respondents in the data live in 256 counties. In our published article, however, we say that the sample includes 1,184 respondents nested within 91 counties. Obviously, that is a big difference. We are claiming in the article that there is an average of 13 respondents per county, when the data actually include fewer than two per county. I also looked at other studies that have used data from the Research Network. Consistent with our data (but not with our article), they have reported fewer than two respondents per county, on average (Pickett et al., 2014; Stupi et al., 2014).

I initially thought this must be the wrong data, even though Eric sent it to me for our paper. Then I looked at the mean (53.04) and standard deviation (13.02) for the variable I collected (Rep_2004). They both are identical to those we report in the published paper. Thus, the variable's descriptives match the published statistics, even though the data are nothing like what we claim, either in terms of the number of respondents or the number of counties.

This led me to dig back through all of the emails I have from Eric in my old FSU account to see if I missed something. I found two emails that worry me. The first is his response when I 
apparently asked him (on September 11,2010) about the large number of counties. He said:

"To answer your question, I created an aggregate shape file that resulted in 91 usable counties. Additionally, I also had to fix the errors from the data Jake and Gertz gave me for the counties. The counties and codes were wrong. Once I got things clean, I was better able to use the data. Anyway that is how I got the 91 counties."

At the time, as a graduate student, I found this explanation convincing. Now, I do not, for several reasons. First, a shapefile wouldn't change the number of counties. Second, although the FIPS codes (Full_FIPS) included in the data Eric sent were wrong (and missing for 365 respondents), the county names (county_n) matched both the city names (city) and the core-based statistical areas (cbsa_tit). When I collected the voting information, I used all of these variables to: 1) double-check the counties, and then 2) distinguish counties with the same name in different states (Adams, CO vs. Adams, NE, and Harrison, MS vs. Harrison, WV). Once I did this, the total number of counties increased from 256 to 292 . Now, maybe these county names were wrong also, and Eric fixed them later that month (December 2009) before we submitted the paper. If so, the percent Republican (mean, SD) would necessarily have changed when he fixed them. You cannot go from 292 counties to 91 without some other numbers also changing.

In another email, Eric sent me the 2009 ASC presentation for our paper (attached). I opened it and looked at the data and findings. In it we say we have a total of 868 Americans, not the 1,000 in the data, or the 1,184 reported in the published article. But many of the descriptive statistics, regression coefficients, and standard errors are identical to those in the published article. I also found a draft of the paper from a few months before we sent the manuscript to Criminology (also attached). It also lists 868 respondents, not 1,184. Again, most of the descriptive statistics, regression coefficients, and standard errors match those in the published article. I counted. There are 293 statistics in the published article, and 258 (88\%) are perfectly identical to those in the unpublished draft, even though the article has 316 additional respondents. Where did these respondents come from? Our published article doesn't say anything about imputation, or adding a later survey. Why didn't the inclusion of 316 new respondents have a larger impact on the statistics (means, standard deviations, regression coefficients, and standard errors)?

I remain hopeful that one of you will share a copy of the data with me that clears up these issues. They appear quite serious to me. Without additional data and a convincing explanation, I will have to retract my name from the article.

Best,

Justin 


\section{APPENDIX B: MULTILEVEL REGRESSION TABLES FROM ARTICLES PUBLISHED BY OTHER AUTHORS}

Table 2. Impact of School Racial Composition on Youth Perception of Injustice

\begin{tabular}{|c|c|c|c|c|}
\hline Variable & Model 1 & Model 2 & Model 3 & Model 4 \\
\hline \multicolumn{5}{|l|}{ Level One: Student } \\
\hline Black & $\begin{array}{l}2.476^{* * * *} \\
(.156)\end{array}$ & $\begin{array}{l}2.552 * * * \\
(.163)\end{array}$ & $\begin{array}{l}2.555^{* * * *} \\
(.169)\end{array}$ & $\begin{array}{l}2.465^{* * * *} \\
(.168)\end{array}$ \\
\hline Asian & $\begin{array}{l}-.068 \\
(.234)\end{array}$ & $\begin{array}{l}-.071 \\
(.233)\end{array}$ & $\begin{array}{c}-.068 \\
(.230)\end{array}$ & $\begin{array}{c}.288 \\
(.204)\end{array}$ \\
\hline Latino & $\begin{array}{l}1.606^{* * * *} \\
(.138)\end{array}$ & $\begin{array}{l}1.627^{* * *} \\
(.139)\end{array}$ & $\begin{array}{l}1.627^{* * *} \\
(.138)\end{array}$ & $\begin{array}{l}1.671^{* * * *} \\
(.140)\end{array}$ \\
\hline American Indian/Alaskan Native & $\begin{array}{l}1.535^{* *} \\
(.425)\end{array}$ & $\begin{array}{l}1.534^{* *} \\
(.428)\end{array}$ & $\begin{array}{l}1.484^{* * *} \\
(.429)\end{array}$ & $\begin{array}{l}1.198^{* *} \\
(.366)\end{array}$ \\
\hline \multicolumn{5}{|l|}{ Controls } \\
\hline Male & - & - & $\begin{array}{l}.575^{* * *} \\
(.055)\end{array}$ & $\begin{array}{l}-.044 \\
(.055)\end{array}$ \\
\hline Ninth grader & - & - & $\begin{array}{l}-.193^{* * *} \\
(.048)\end{array}$ & $\begin{array}{l}-.201^{* * * *} \\
(.048)\end{array}$ \\
\hline \multicolumn{5}{|l|}{ Mom's education } \\
\hline High school graduate & - & - & $\begin{array}{l}-.121 \\
(.069)\end{array}$ & $\begin{array}{l}-.072 \\
(.063)\end{array}$ \\
\hline Vocational/trade school & - & - & $\begin{array}{l}-.075 \\
(.144)\end{array}$ & $\begin{array}{l}-.143 \\
(.142)\end{array}$ \\
\hline Some college & - & - & $\begin{array}{l}.129 \\
(.076)\end{array}$ & $\begin{array}{l}.163^{*} \\
(.076)\end{array}$ \\
\hline College graduate & - & - & $\begin{array}{l}-.064 \\
(.077)\end{array}$ & $\begin{array}{l}.005 \\
(.076)\end{array}$ \\
\hline Advanced degree & - & - & $\begin{array}{l}-.019 \\
(.095)\end{array}$ & $\begin{array}{c}.012 \\
(.094)\end{array}$ \\
\hline Personal contact with police & - & - & - & $\begin{array}{l}.306 * * * \\
(.012)\end{array}$ \\
\hline Personal trouble in school & - & - & - & $\begin{array}{c}.013 \\
(.009)\end{array}$ \\
\hline \multicolumn{5}{|l|}{ Level Two: School } \\
\hline Percent white & - & $\begin{array}{l}.046^{* *} \\
(.012)\end{array}$ & $\begin{array}{l}.044^{* *} \\
(.013)\end{array}$ & $\begin{array}{l}.036^{* *} \\
(.013)\end{array}$ \\
\hline Percent white squared & - & $\begin{array}{l}-.0008^{* *} \\
(.0003)\end{array}$ & $\begin{array}{c}-.0008^{*} \\
(.0003)\end{array}$ & $\begin{array}{c}-.0007 * \\
(.0003)\end{array}$ \\
\hline \multicolumn{5}{|l|}{ Controls } \\
\hline School $50 \%-80 \%$ low income & - & - & $\begin{array}{c}.071 \\
(.139)\end{array}$ & $\begin{array}{c}.127 \\
(.139)\end{array}$ \\
\hline School $80 \%-95 \%$ low income & - & - & $\begin{array}{l}-.064 \\
(.115)\end{array}$ & $\begin{array}{l}-.055 \\
(.130)\end{array}$ \\
\hline Average student contact with police & - & - & - & $\begin{array}{l}-.210 \\
(.111)\end{array}$ \\
\hline Average student trouble in school & - & - & - & $\begin{array}{c}-.128^{*} \\
(.058)\end{array}$ \\
\hline Constant & $\begin{array}{c}12.472 * * * \\
(.135)\end{array}$ & $\begin{array}{c}12.208^{* * *} \\
(.173)\end{array}$ & $\begin{array}{l}12.120^{* * * *} \\
(.215)\end{array}$ & $\begin{array}{c}12.565^{* * * *} \\
(.272)\end{array}$ \\
\hline Level One Variance & 8.718 & 8.718 & 8.626 & 7.900 \\
\hline Explained Variation & .057 & .057 & .067 & .146 \\
\hline Level Two Variance & .149 & .100 & .097 & .090 \\
\hline Explained Variation & .429 & .617 & .628 & .655 \\
\hline Level One N & 18251 & 18251 & 18251 & 18251 \\
\hline Level Two N & 91 & 91 & 91 & 91 \\
\hline
\end{tabular}


Table 3. Impact of School Racial Composition on White Youth Perception of Injustice

\begin{tabular}{|c|c|c|c|}
\hline Variable & Model 1 & Model 2 & Model : \\
\hline \multicolumn{4}{|l|}{ Level One: Student } \\
\hline \multicolumn{4}{|l|}{ Controls } \\
\hline Male & - & $\begin{array}{l}.674^{* * * *} \\
(.121)\end{array}$ & $\begin{array}{c}.152 \\
(.114)\end{array}$ \\
\hline Ninth grader & - & $\begin{array}{l}-.139 \\
(.178)\end{array}$ & $\begin{array}{c}-.118 \\
(.167)\end{array}$ \\
\hline \multicolumn{4}{|l|}{ Mom's education } \\
\hline High school graduate & - & $\begin{array}{c}-.338 \\
(.188)\end{array}$ & $\begin{array}{c}-.085 \\
(.166)\end{array}$ \\
\hline Vocational/trade school & - & $\begin{array}{l}-.208 \\
(.293)\end{array}$ & $\begin{array}{c}.154 \\
(.275)\end{array}$ \\
\hline Some college & - & $\begin{array}{c}-.351 \\
(.252)\end{array}$ & $\begin{array}{l}-.110 \\
(.217)\end{array}$ \\
\hline College graduate & - & $\begin{array}{l}-.343 \\
(.179)\end{array}$ & $\begin{array}{l}-.047 \\
(.149)\end{array}$ \\
\hline Advanced degree & - & $\begin{array}{l}-.426 \\
(.246)\end{array}$ & $\begin{array}{c}-.022 \\
(.209)\end{array}$ \\
\hline Personal contact with police & - & - & $\begin{array}{l}.339 * * \\
(.033)\end{array}$ \\
\hline Personal trouble in school & - & - & $\begin{array}{l}.060 * * \\
(.023)\end{array}$ \\
\hline \multicolumn{4}{|l|}{ Level Two: School } \\
\hline Racial composition: percent white & $\begin{array}{l}-.015 \\
(.015)\end{array}$ & $\begin{array}{c}-.011 \\
(.020)\end{array}$ & $\begin{array}{r}-.0007 \\
(.019)\end{array}$ \\
\hline Racial composition: percent white squared & $\begin{array}{c}.00004 \\
(.0003)\end{array}$ & $\begin{array}{l}-.000004 \\
(.0003)\end{array}$ & $\begin{array}{c}-.00008 \\
(.0003)\end{array}$ \\
\hline \multicolumn{4}{|l|}{ Controls } \\
\hline School $50 \%-80 \%$ low income & - & $\begin{array}{l}.338 \\
(.265)\end{array}$ & $\begin{array}{l}.255 \\
(.259)\end{array}$ \\
\hline School $80 \%-95 \%$ low income & - & $\begin{array}{l}.199 \\
(.235)\end{array}$ & $\begin{array}{c}.104 \\
(.243)\end{array}$ \\
\hline Average student contact with police & - & - & $\begin{array}{c}-.224 \\
(.141)\end{array}$ \\
\hline Average student trouble in school & - & - & $\begin{array}{c}.074 \\
(.141)\end{array}$ \\
\hline Constant & $\begin{array}{c}13.108 * * * \\
(.250)\end{array}$ & $\begin{array}{c}12.882 * * * \\
(.433)\end{array}$ & $\begin{array}{c}12.170^{* *} \\
(.509)\end{array}$ \\
\hline Level One Variance & 7.875 & 7.765 & 6.694 \\
\hline Explained Variation & -.0005 & .013 & .150 \\
\hline Level Two Variance & .135 & .129 & .130 \\
\hline Explained Variation & .167 & .204 & .198 \\
\hline Level One N & 2371 & 2371 & 2371 \\
\hline Level Two N & 45 & 45 & 45 \\
\hline
\end{tabular}


Table 4. Impact of School Racial Composition on Black Youth Perception of Injustice

\begin{tabular}{|c|c|c|c|}
\hline Variable & Model 1 & Model 2 & Model 3 \\
\hline \multicolumn{4}{|l|}{ Level One: Student } \\
\hline Male & - & $\begin{array}{l}.372 * * * \\
(.078)\end{array}$ & $\begin{array}{l}-.219 * * \\
(.080)\end{array}$ \\
\hline Ninth grader & - & $\begin{array}{l}-.213^{* *} \\
(.077)\end{array}$ & $\begin{array}{l}-.197^{* * *} \\
(.071)\end{array}$ \\
\hline \multicolumn{4}{|l|}{ Mom's education } \\
\hline High school graduate & - & $\begin{array}{l}-.103 \\
(.107)\end{array}$ & $\begin{array}{c}-.019 \\
(.100)\end{array}$ \\
\hline Vocational/trade school & - & $\begin{array}{l}-.172 \\
(.235)\end{array}$ & $\begin{array}{l}-.212 \\
(.234)\end{array}$ \\
\hline Some college & - & $\begin{array}{l}.350 * * * \\
(.092)\end{array}$ & $\begin{array}{l}.444 * * * \\
(.093)\end{array}$ \\
\hline College graduate & - & $\begin{array}{c}.051 \\
(.136)\end{array}$ & $\begin{array}{l}.164 \\
(.131)\end{array}$ \\
\hline Advanced degree & - & $\begin{array}{l}.084 \\
(.137)\end{array}$ & $\begin{array}{c}.152 \\
(.130)\end{array}$ \\
\hline Personal contact with police & - & - & $\begin{array}{l}.260 * * * \\
(.014)\end{array}$ \\
\hline Personal trouble in school & - & - & $\begin{array}{c}.000 \\
(.013)\end{array}$ \\
\hline \multicolumn{4}{|l|}{ Level Two: School } \\
\hline Racial composition: percent white & $\begin{array}{l}.074 * * * \\
(.016)\end{array}$ & $\begin{array}{l}.068^{* * * *} \\
(.016)\end{array}$ & $\begin{array}{l}.066^{* * *} \\
(.017)\end{array}$ \\
\hline Racial composition: percent white squared & $\begin{array}{l}-.0015^{* *} \\
(.0004)\end{array}$ & $\begin{array}{l}-.0014^{* *} \\
(.0004)\end{array}$ & $\begin{array}{l}-.0014 * * \\
(.0004)\end{array}$ \\
\hline \multicolumn{4}{|l|}{ Controls } \\
\hline School $50-80 \%$ low income & - & $\begin{array}{l}-.069 \\
(.191)\end{array}$ & $\begin{array}{c}-.058 \\
(.179)\end{array}$ \\
\hline School $80-95 \%$ low income & - & $\begin{array}{l}-.148 \\
(.155)\end{array}$ & $\begin{array}{l}-.153 \\
(.175)\end{array}$ \\
\hline Average student contact with police & - & - & $\begin{array}{l}-.169 \\
(.124)\end{array}$ \\
\hline Average student trouble in school & - & - & $\begin{array}{l}-.089 \\
(.059)\end{array}$ \\
\hline Constant & $\begin{array}{c}14.669 * * * \\
(.085)\end{array}$ & $\begin{array}{c}14.697^{* * * *} \\
(.178)\end{array}$ & $\begin{array}{c}14.946 * * * \\
(.272)\end{array}$ \\
\hline Level One Variance & 9.391 & 9.334 & 8.827 \\
\hline Explained Variation & .000 & .006 & .060 \\
\hline Level Two Variance & .142 & .132 & .134 \\
\hline Explained Variation & .401 & .443 & .435 \\
\hline Level One N & 8151 & 8151 & 8151 \\
\hline Level Two $\mathrm{N}$ & 80 & 80 & 80 \\
\hline
\end{tabular}


Table 5. Impact of School Racial Composition on Latino Youth Perception of Injustice

\begin{tabular}{|c|c|c|c|}
\hline Variable & Model 1 & Model 2 & Model 3 \\
\hline \multicolumn{4}{|l|}{ Level One: Student } \\
\hline Male & - & $\begin{array}{l}.709 * * * \\
(.090)\end{array}$ & $\begin{array}{c}-.011 \\
(.090)\end{array}$ \\
\hline Ninth grader & - & $\begin{array}{l}-.228 * * \\
(.068)\end{array}$ & $\begin{array}{l}-.262 * * * \\
(.070)\end{array}$ \\
\hline \multicolumn{4}{|l|}{ Mom's education } \\
\hline High school graduate & - & $\begin{array}{l}-.065 \\
(.102)\end{array}$ & $\begin{array}{l}-.068 \\
(.089)\end{array}$ \\
\hline Vocational/trade school & - & $\begin{array}{c}.081 \\
(.221)\end{array}$ & $\begin{array}{c}-.083 \\
(.203)\end{array}$ \\
\hline Some college & - & $\begin{array}{l}-.090 \\
(.095)\end{array}$ & $\begin{array}{c}-.205^{*} \\
(.089)\end{array}$ \\
\hline College graduate & - & $\begin{array}{c}-.061 \\
(.104)\end{array}$ & $\begin{array}{l}-.095 \\
(.091)\end{array}$ \\
\hline Advanced degree & - & $\begin{array}{c}.100 \\
(.148)\end{array}$ & $\begin{array}{l}-.062 \\
(.151)\end{array}$ \\
\hline Personal contact with police & - & - & $\begin{array}{l}.363^{* * *} \\
(.013)\end{array}$ \\
\hline Personal trouble in school & - & - & $\begin{array}{c}.002 \\
(.011)\end{array}$ \\
\hline \multicolumn{4}{|l|}{ Level Two: School } \\
\hline Racial composition: percent white & $\begin{array}{c}.039^{*} \\
(.019)\end{array}$ & $\begin{array}{c}.038 \\
(.021)\end{array}$ & $\begin{array}{c}.044 * \\
(.018)\end{array}$ \\
\hline Racial composition: percent white squared & $\begin{array}{c}-.00082 \\
(.00043)\end{array}$ & $\begin{array}{l}-.00083 \\
(.00046)\end{array}$ & $\begin{array}{c}-.00099 * \\
(.00041)\end{array}$ \\
\hline \multicolumn{4}{|l|}{ Controls } \\
\hline School $50-80 \%$ low income & - & $\begin{array}{c}-.093 \\
(.213)\end{array}$ & $\begin{array}{c}-.272 \\
(.200)\end{array}$ \\
\hline School $80-95 \%$ low income & - & $\begin{array}{c}-.132 \\
(.218)\end{array}$ & $\begin{array}{l}-.250 \\
(.169)\end{array}$ \\
\hline Average student contact with police & - & - & $\begin{array}{c}.093 \\
(.135)\end{array}$ \\
\hline Average student trouble in school & - & - & $\begin{array}{l}-.121 \\
(.087)\end{array}$ \\
\hline Constant & $\begin{array}{c}13.964 * * * \\
(.106)\end{array}$ & $\begin{array}{c}13.909 * * * \\
(.270)\end{array}$ & $\begin{array}{c}13.669 * * * \\
(.378)\end{array}$ \\
\hline Level One Variance & 8.223 & 8.093 & 7.124 \\
\hline Explained Variation & .000 & .016 & .134 \\
\hline Level Two Variance & .106 & .119 & .070 \\
\hline Explained Variation & .086 & -.026 & .400 \\
\hline Level One N & 6815 & 6815 & 6815 \\
\hline Level Two N & 71 & 71 & 71 \\
\hline
\end{tabular}


Table 3. Racial/Ethnic Disparities in Arrest, With Individual and Neighborhood Characteristics

\begin{tabular}{|c|c|c|c|c|c|c|}
\hline \multirow[b]{2}{*}{ Variables } & \multicolumn{2}{|c|}{ Model 1} & \multicolumn{2}{|c|}{ Model 2} & \multicolumn{2}{|c|}{ Model 3} \\
\hline & Coefficient & $S E$ & Coefficient & $S E$ & Coefficient & $S E$ \\
\hline $\begin{array}{l}\text { Intercept (expected coun } \\
\text { at age 17) }\end{array}$ & $-2.408^{* * *}$ & 0.067 & $-2.418^{* * *}$ & 0.068 & $-2.389^{* * *}$ & 0.070 \\
\hline \multicolumn{7}{|c|}{ Neighborhood-Level Variables } \\
\hline$\%$ white & & & 0.041 & 0.048 & & \\
\hline$\%$ Mexican & & & -0.060 & 0.031 & & \\
\hline$\%$ other Latino & & & $0.118^{*}$ & 0.054 & & \\
\hline$\%$ other race & & & 0.073 & 0.102 & & \\
\hline Concentrated poverty & & & & & $0.190^{*}$ & 0.075 \\
\hline$\%$ foreign-born & & & & & -0.007 & 0.008 \\
\hline Residential stability & & & & & $-0.185^{*}$ & 0.078 \\
\hline \multicolumn{7}{|l|}{ Individual-Level Variables } \\
\hline \multicolumn{7}{|c|}{ Race/Ethnicity (vs. black) } \\
\hline White & $-1.151^{* * *}$ & 0.156 & $-1.370^{* * *}$ & 0.265 & $-0.913^{* * *}$ & 0.163 \\
\hline Mexican & $-1.074^{* * *}$ & 0.169 & $-1.011^{* * *}$ & 0.238 & $-0.936^{* * *}$ & 0.248 \\
\hline Other Latino & $-1.032^{* * *}$ & 0.118 & $-1.181^{* * *}$ & 0.181 & $-0.916^{* * *}$ & 0.133 \\
\hline Other race & $-1.414^{* * *}$ & 0.280 & $-1.579^{* * *}$ & 0.317 & $-1.238^{* * *}$ & 0.273 \\
\hline Male & $1.842^{* * *}$ & 0.120 & $1.844^{* * *}$ & 0.117 & $1.837^{* * *}$ & 0.120 \\
\hline \multicolumn{7}{|l|}{ Cohort (vs. cohort 12) } \\
\hline Cohort 15 & $-0.705^{* * * *}$ & 0.123 & $-0.701^{* * *}$ & 0.122 & $-0.667^{* * *}$ & 0.123 \\
\hline Cohort 18 & $-0.903^{* * * *}$ & 0.139 & $-0.913^{* * *}$ & 0.139 & $-0.843^{* * *}$ & 0.140 \\
\hline Age & $0.455^{* * *}$ & 0.024 & $0.453^{* * *}$ & 0.024 & $0.456^{* * *}$ & 0.024 \\
\hline $\mathrm{Age}^{2}$ & $-0.087^{* * *}$ & 0.005 & $-0.086^{* * *}$ & 0.005 & $-0.087^{* * *}$ & 0.005 \\
\hline
\end{tabular}


Table 4. Racial/Ethnic Disparities in Arrest, With Individual, Family, and Neighborhood Characteristics

\begin{tabular}{|c|c|c|c|c|c|c|c|c|}
\hline \multirow[b]{2}{*}{ Variables } & \multicolumn{2}{|c|}{ Model 4} & \multicolumn{2}{|c|}{ Model 5} & \multicolumn{2}{|c|}{ Model 6} & \multicolumn{2}{|c|}{ Model 7} \\
\hline & Coefficient & $S E$ & Coefficient & $S E$ & Coefficient & $S E$ & Coefficient & $S E$ \\
\hline $\begin{array}{l}\text { Intercept (expected count } \\
\text { of arrests at age 17) }\end{array}$ & $-2.392^{* * *}$ & 0.070 & $-2.502^{* * *}$ & 0.069 & $-2.609^{* * *}$ & 0.068 & $-2.623^{* * *}$ & 0.070 \\
\hline \multicolumn{9}{|c|}{ Neighborhood-Level Variables } \\
\hline Concentrated poverty & $0.309^{* *}$ & 0.096 & $0.207^{*}$ & 0.094 & $0.214^{*}$ & 0.093 & $0.232^{*}$ & 0.100 \\
\hline$\%$ foreign-born & 0.000 & 0.007 & 0.006 & 0.007 & 0.008 & 0.006 & 0.009 & 0.006 \\
\hline Residential stability & -0.160 & 0.094 & -0.093 & 0.091 & -0.088 & 0.097 & -0.043 & 0.106 \\
\hline Collective efficacy & 0.477 & 0.483 & 0.351 & 0.423 & 0.360 & 0.478 & 0.334 & 0.558 \\
\hline Tolerance of deviance & 0.644 & 0.481 & 0.728 & 0.503 & 0.977 & 0.507 & $1.235^{*}$ & 0.540 \\
\hline \multicolumn{9}{|l|}{ Individual-Level Variables } \\
\hline \multicolumn{9}{|c|}{ Race/Ethnicity (vs. black) } \\
\hline White & $-0.952^{* * *}$ & 0.176 & $-0.651^{* * *}$ & 0.196 & $-0.632^{* *}$ & 0.199 & $-0.587^{* *}$ & 0.207 \\
\hline Mexican & $-0.955^{* * *}$ & 0.221 & -0.425 & 0.246 & $-0.488^{*}$ & 0.240 & $-0.503^{*}$ & 0.252 \\
\hline Other Latino & $-0.914^{* * *}$ & 0.124 & $-0.451^{* *}$ & 0.158 & $-0.561^{* * *}$ & 0.156 & $-0.567^{* * *}$ & 0.166 \\
\hline Other race & $-1.278^{* * *}$ & 0.291 & $-0.900^{* * *}$ & 0.268 & $-1.106^{* * *}$ & 0.222 & $-1.159^{* * *}$ & 0.217 \\
\hline Male & $1.825^{* * *}$ & 0.121 & $1.843^{* * *}$ & 0.119 & $1.731^{* * *}$ & 0.118 & $1.735^{* * *}$ & 0.120 \\
\hline \multicolumn{9}{|l|}{ Cohort (vs. cohort 12) } \\
\hline Cohort 15 & $-0.656^{* * *}$ & 0.123 & $-0.695^{* * *}$ & 0.132 & $-1.019^{* * *}$ & 0.132 & $-1.017^{* * *}$ & 0.135 \\
\hline Cohort 18 & $-0.843^{* * *}$ & 0.143 & $-0.840^{* * *}$ & 0.161 & $-1.124^{* * *}$ & 0.155 & $-1.141^{* * *}$ & 0.156 \\
\hline Age & $0.457^{* * *}$ & 0.024 & $0.457^{* * *}$ & 0.024 & $0.458^{* * *}$ & 0.023 & $0.458^{* * *}$ & 0.023 \\
\hline $\mathrm{Age}^{2}$ & $-0.087^{* * *}$ & 0.005 & $-0.087^{* * *}$ & 0.005 & $-0.087^{* * *}$ & 0.005 & $-0.087^{* * *}$ & 0.005 \\
\hline \multicolumn{9}{|l|}{$\begin{array}{l}\text { Immigrant generation } \\
\text { (vs. third or higher) }\end{array}$} \\
\hline First generation & & & $-0.667^{* *}$ & 0.231 & -0.349 & 0.248 & -0.338 & 0.253 \\
\hline Second generation & & & $-0.646^{* * *}$ & 0.195 & $-0.557^{* *}$ & 0.187 & $-0.548^{* *}$ & 0.191 \\
\hline $\begin{array}{l}\text { Family socioeconomic } \\
\text { status }\end{array}$ & & & -0.081 & 0.049 & $-0.110^{*}$ & 0.052 & $-0.125^{*}$ & 0.054 \\
\hline Married parents & & & $-0.718^{* * *}$ & 0.112 & $-0.693^{* * *}$ & 0.116 & $-0.688^{* * *}$ & 0.114 \\
\hline Adult extended family & & & 0.152 & 0.121 & 0.207 & 0.131 & 0.251 & 0.132 \\
\hline Number of children & & & $0.048^{*}$ & 0.023 & 0.040 & 0.024 & 0.040 & 0.025 \\
\hline Family control & & & 0.000 & 0.006 & 0.002 & 0.006 & 0.004 & 0.006 \\
\hline $\begin{array}{l}\text { Self-reported criminal } \\
\text { offending (SRO) }\end{array}$ & & & & & $0.564^{* * *}$ & 0.060 & $0.598^{* * *}$ & 0.061 \\
\hline SRO $\times$ Concentrate & poverty & & & & & & -0.105 & 0.110 \\
\hline $\mathrm{SRO} \times \%$ foreign-bc & & & & & & & -0.005 & 0.006 \\
\hline SRO $\times$ Residential $s$ & ability & & & & & & $-0.214^{*}$ & 0.085 \\
\hline SRO $\times$ Collective eff & icacy & & & & & & 0.221 & 0.467 \\
\hline SRO $\times$ Tolerance of & deviance & & & & & & $-1.373^{* * *}$ & 0.412 \\
\hline
\end{tabular}


Table 2. Multilevel Model of Arrest with Individual, Family, and Neighborhood Characteristics

\begin{tabular}{|c|c|c|c|c|c|c|}
\hline \multirow[b]{2}{*}{ Variables } & \multicolumn{2}{|c|}{ Model 1} & \multicolumn{2}{|c|}{ Model 2} & \multicolumn{2}{|c|}{ Model 3} \\
\hline & Coefficient & (SE) & Coefficient & (SE) & Coefficient & (SE) \\
\hline Intercept (frequency of arrest) & $-.977^{* * *}$ & $(.096)$ & $-.994^{* * * *}$ & $(.089)$ & $-1.004^{* * *}$ & $(.090)$ \\
\hline $\begin{array}{l}\text { Neighborhood-level }(N=78) \\
\text { Proportion Black } \\
\text { Proportion Latino }\end{array}$ & & & $\begin{array}{l}-.861^{*} \\
-.057\end{array}$ & $\begin{array}{l}(.407) \\
(.515)\end{array}$ & $\begin{array}{c}-.682 \dagger \\
.030\end{array}$ & $\begin{array}{l}(.395) \\
(.507)\end{array}$ \\
\hline $\begin{array}{l}\text { Individual-level }(N=1,071) \\
\text { White } \\
\text { Mexican } \\
\text { Other Latino } \\
\text { Other race } \\
\text { Male } \\
\text { Cohort } 15 \\
\text { Family socioeconomic status } \\
\text { Married parents } \\
\text { Family control } \\
\text { Self-reported criminal offending } \\
\text { SRO } \times \text { proportion Black } \\
\text { SRO } \times \text { proportion Latino }\end{array}$ & $\begin{array}{c}-1.166^{* * * *} \\
-.756^{* *} \\
-1.066^{* * * *} \\
-1.027^{* * * *} \\
1.957^{* * * *} \\
-.212 \\
-.061 \\
-.591^{* * * *} \\
.011 \\
.542^{* * * *}\end{array}$ & $\begin{array}{l}(.297) \\
(.263) \\
(.260) \\
(.294) \\
(.169) \\
(.144) \\
(.073) \\
(.178) \\
(.008) \\
(.093)\end{array}$ & $\begin{array}{c}-1.573^{\text {**** }} \\
-1.102^{\text {**** }} \\
-1.406^{* * * *} \\
-1.400^{* * * *} \\
1.970^{\text {*** }} \\
-.188 \\
-.065 \\
-.584^{* *} \\
.009 \\
.538^{* * *}\end{array}$ & $\begin{array}{l}(.374) \\
(.322) \\
(.300) \\
(.381) \\
(.172) \\
(.148) \\
(.077) \\
(.187) \\
(.008) \\
(.089)\end{array}$ & $\begin{aligned}-1.625^{* * *} \\
-1.129^{* * *} \\
-1.419^{* * *} \\
-1.471^{* * *} \\
1.964^{* * *} \\
-.177 \\
-.060 \\
-.581^{* *} \\
.009 \\
.545^{* * *} \\
-.489 \dagger \\
-.164\end{aligned}$ & $\begin{array}{l}(.390) \\
(.320) \\
(.305) \\
(.404) \\
(.171) \\
(.145) \\
(.077) \\
(.185) \\
(.008) \\
(.089) \\
(.283) \\
(.367)\end{array}$ \\
\hline
\end{tabular}


Table 3. The Effect of Legal Cynicism and Collective Efficacy on Arrest

\begin{tabular}{|c|c|c|c|c|c|c|}
\hline \multirow[b]{2}{*}{ Variables } & \multicolumn{2}{|c|}{ Model 4} & \multicolumn{2}{|c|}{ Model 5} & \multicolumn{2}{|c|}{ Model 6} \\
\hline & Coefficient & $(\mathrm{SE})$ & Coefficient & $(\mathrm{SE})$ & Coefficient & (SE) \\
\hline Intercept (frequency of arrest) & $-1.036^{* * *}$ & $(.088)$ & $-1.033^{* * *}$ & $(.087)$ & $-1.050^{* * *}$ & $(.092)$ \\
\hline \multicolumn{7}{|l|}{ Neighborhood-level $(N=78)$} \\
\hline Proportion Black & $-1.667^{* *}$ & $(.582)$ & $-1.660^{* * *}$ & $(.571)$ & $-1.690^{* *}$ & $(.593)$ \\
\hline Proportion Latino & $-1.259 \dagger$ & $(.738)$ & -1.133 & $(.734)$ & -1.056 & $(.732)$ \\
\hline Legal cynicism & $.650^{* * *}$ & $(.227)$ & $.548^{*}$ & $(.272)$ & $.636^{*}$ & $(.284)$ \\
\hline Concentrated poverty & & & .111 & $(.144)$ & .126 & $(.155)$ \\
\hline Calls for service (log) & & & .029 & $(.124)$ & .016 & $(.121)$ \\
\hline Collective efficacy & & & & & .364 & $(.410)$ \\
\hline White & $-1.538^{* * *}$ & $(.383)$ & $-1.530^{* * *}$ & $(.375)$ & $-1.528^{* * *}$ & $(.389)$ \\
\hline Mexican & $-1.048^{* * *}$ & $(.305)$ & $-1.048^{* * *}$ & $(.302)$ & $-1.137^{* * *}$ & $(.290)$ \\
\hline Other Latino & $-1.360^{\text {*** }}$ & $(.290)$ & $-1.364^{* * *}$ & $(.284)$ & $-1.393^{* * *}$ & $(.289)$ \\
\hline Other race & $-1.388^{* * *}$ & $(.391)$ & $-1.389^{* * *}$ & $(.394)$ & $-1.464^{* * *}$ & $(.436)$ \\
\hline Male & $1.967^{* * * *}$ & $(.174)$ & $1.965^{* * *}$ & $(.172)$ & $1.934^{* * *}$ & $(.179)$ \\
\hline Cohort 15 & -.165 & $(.143)$ & -.171 & $(.147)$ & -.149 & $(.146)$ \\
\hline Family socioeconomic status & -.043 & $(.078)$ & -.040 & $(.080)$ & -.059 & $(.077)$ \\
\hline Married parents & $-.573^{* *}$ & $(.187)$ & $-.560^{* *}$ & $(.190)$ & $-.556^{* *}$ & $(.194)$ \\
\hline Family control & .008 & $(.009)$ & .008 & $(.009)$ & .007 & $(.009)$ \\
\hline Self-reported criminal offending & $.586^{* * * *}$ & $(.083)$ & $.591^{* * *}$ & $(.082)$ & $.514^{* * *}$ & $(.083)$ \\
\hline SRO $\times$ proportion Black & .331 & $(.476)$ & .254 & $(.498)$ & -.277 & $(.492)$ \\
\hline SRO $\times$ proportion Latino & .859 & $(.643)$ & .800 & $(.717)$ & .531 & $(.670)$ \\
\hline SRO $\times$ legal cynicism & $-.526^{* *}$ & $(.188)$ & $-.584^{*}$ & $(.247)$ & -.026 & $(.279)$ \\
\hline SRO $\times$ concentrated poverty & & & .108 & $(.157)$ & .216 & $(.147)$ \\
\hline SRO $\times$ calls for service $(\log )$ & & & .021 & $(.154)$ & -.042 & $(.157)$ \\
\hline SRO $\times$ collective efficacy & & & & & $1.544^{* * *}$ & $(.421)$ \\
\hline
\end{tabular}


TABLE 2-Social Anatomy of Racial/Ethnic Disparities in Violence: Project on Human Development

in Chicago Neighborhoods Waves 1-3, Age Cohorts $9-18^{\mathrm{a}}$

\begin{tabular}{|c|c|c|c|c|c|}
\hline & $\begin{array}{c}\text { Model 1, } \\
\text { Coefficient (SE) }\end{array}$ & $\begin{array}{c}\text { Model 2, } \\
\text { Coefficient (SE) }\end{array}$ & $\begin{array}{c}\text { Model 3, } \\
\text { Coefficient (SE) }\end{array}$ & $\begin{array}{c}\text { Model 4, } \\
\text { Coefficient (SE) }\end{array}$ & $\begin{array}{c}\text { Model } 5, \\
\text { Coefficient (SE) }\end{array}$ \\
\hline Intercept & $-1.178(0.036)^{* *}$ & $-1.022(0.360)^{* *}$ & $-1.033(0.356)^{* *}$ & $-1.020(0.361)^{* *}$ & $-1.023(0.043)^{* *}$ \\
\hline \multicolumn{6}{|l|}{ Race/ethnicity } \\
\hline Black & $0.614(0.043)^{* *}$ & $0.528(0.044)^{* *}$ & $0.401(0.046)^{* *}$ & $0.368(0.047)^{* *}$ & $0.247(0.087)^{* *}$ \\
\hline Mexican American & $-0.101(0.042)^{*}$ & $0.123(0.052)^{*}$ & $0.066(0.056)$ & $0.065(0.055)$ & $0.034(0.058)$ \\
\hline Puerto Rican/other Latino & $0.229(0.063)^{* *}$ & $0.228(0.124)$ & $0.116(0.117)$ & $0.100(0.113)$ & $0.074(0.115)$ \\
\hline Other race & $0.190(0.095)^{*}$ & $0.287(0.093)^{* *}$ & $0.236(0.088)^{* *}$ & $0.210(0.089)^{*}$ & $0.139(0.105)$ \\
\hline \multicolumn{6}{|l|}{ Gender/age } \\
\hline Male & $0.495(0.030)^{* *}$ & $0.501(0.030)^{* *}$ & $0.520(0.029)^{* *}$ & $0.502(0.029)^{* *}$ & $0.507(0.032)^{* *}$ \\
\hline Linear age $^{b}$ & $0.060(0.004)^{* *}$ & $0.065(0.004)^{* *}$ & $0.069(0.004)^{* *}$ & $0.059(0.005)^{* *}$ & $0.060(0.005)^{* *}$ \\
\hline Quadratic age ${ }^{c}$ & $-0.020(0.002)^{* *}$ & $-0.020(0.002)^{* *}$ & $-0.020(0.001)^{* *}$ & $-0.022(0.001)^{* *}$ & $-0.022(0.001)^{* *}$ \\
\hline \multicolumn{6}{|l|}{ Immigrant status } \\
\hline 1st-generation immigrant & & $-0.636(0.052)^{* *}$ & $-0.644(0.056)^{* *}$ & $-0.588(0.056)^{* *}$ & $-0.585(0.057)^{* *}$ \\
\hline Puerto Rican/other Latino ${ }^{d}$ & & $0.588(0.189)^{* *}$ & $0.539(0.180)^{* *}$ & $0.449(0.170)^{* *}$ & $0.455(0.145)^{* *}$ \\
\hline 2nd-generation immigrant & & $-0.266(0.049)^{* *}$ & $-0.234(0.049)^{* *}$ & $-0.248(0.049)^{* *}$ & $-0.242(0.053)^{* *}$ \\
\hline Puerto Rican/other Latino ${ }^{e}$ & & $0.129(0.144)$ & $0.111(0.138)$ & $0.101(0.135)$ & $0.104(0.116)$ \\
\hline \multicolumn{6}{|l|}{ Family structure } \\
\hline 2 parents, both biological & & & $-0.055(0.056)$ & $-0.029(0.056)$ & $-0.030(0.057)$ \\
\hline 2 parents, 1 /both not biological & & & $0.020(0.048)$ & $0.023(0.047)$ & $0.021(0.049)$ \\
\hline 1 parent, not biological & & & $-0.032(0.081)$ & $-0.045(0.082)$ & $-0.050(0.078)$ \\
\hline Married parents & & & $-0.215(0.050)^{* *}$ & $-0.203(0.050)^{* *}$ & $-0.204(0.049)^{* *}$ \\
\hline Adult extended family & & & $0.020(0.037)$ & $0.013(0.037)$ & $0.008(0.032)$ \\
\hline No. of children & & & $0.002(0.009)$ & $0.001(0.009)$ & $-0.001(0.009)$ \\
\hline \multicolumn{6}{|l|}{ SES/residential context } \\
\hline SES & & & $-0.019(0.014)$ & $-0.014(0.014)$ & $-0.014(0.015)$ \\
\hline Years at same address & & & $-0.015(0.003)^{* *}$ & $-0.014(0.003)^{* *}$ & $-0.016(0.004)^{* *}$ \\
\hline \multicolumn{6}{|l|}{ Individual differences } \\
\hline Verbal/reading ability & & & & $-0.004(0.001)^{* *}$ & $-0.004(0.002)^{*}$ \\
\hline 1st-generation immigrant ${ }^{f}$ & & & & $0.017(0.003)^{* *}$ & $0.016(0.003)^{* *}$ \\
\hline 2nd-generation immigrant ${ }^{g}$ & & & & $0.009(0.002)^{* *}$ & $0.009(0.002)^{* *}$ \\
\hline Impulsivity/hyperactivity & & & & $0.280(0.025)^{* *}$ & $0.281(0.025)^{* *}$ \\
\hline \multicolumn{6}{|l|}{ Neighborhood characteristics } \\
\hline \% African American ${ }^{\mathrm{h}}$ & & & & & $0.224(0.106)^{*}$ \\
\hline$\%$ Mexican American ${ }^{\mathrm{h}}$ & & & & & $0.093(0.108)$ \\
\hline \% Puerto Rican/other Latino ${ }^{\mathrm{h}}$ & & & & & $0.026(0.174)$ \\
\hline$\%$ other race $e^{h}$ & & & & & $0.375(0.255)$ \\
\hline
\end{tabular}


TABLE 3-Neighborhood Predictors of Violence: Project on Human Development in Chicago Neighborhoods Waves 1-3, Age Cohorts $9-18^{\mathrm{a}, \mathrm{b}}$

\begin{tabular}{|c|c|c|c|}
\hline & $\begin{array}{c}\text { Model 1, } \\
\text { Coefficient (SE) }\end{array}$ & $\begin{array}{c}\text { Model 2, } \\
\text { Coefficient (SE) }\end{array}$ & $\begin{array}{c}\text { Model } 3, \\
\text { Coefficient (SE) }\end{array}$ \\
\hline Intercept & $-1.050(0.043)^{* *}$ & $-1.056(0.044)^{* *}$ & $-1.049(0.043)^{* *}$ \\
\hline$\%$ Black $^{c}$ & $0.031(0.095)$ & & \\
\hline$\%$ 1st-generation immigrant ${ }^{c}$ & $-0.524(0.154)^{* *}$ & $-0.563(0.125)^{* *}$ & $-0.532(0.108)^{* *}$ \\
\hline$\%$ professional/managerial occupation ${ }^{\mathrm{C}}$ & $-0.652(0.220)^{* *}$ & $-0.659(0.196)^{* *}$ & $-0.511(0.178)^{* *}$ \\
\hline Concentrated disadvantage & $0.027(0.028)$ & & \\
\hline Residential stability & $-0.009(0.019)$ & & \\
\hline Moral/legal cynicism & & $0.045(0.019)^{*}$ & $0.040(0.019)^{*}$ \\
\hline Collective efficacy & & $0.002(0.022)$ & \\
\hline Friend/kin ties & & $-0.018(0.022)$ & \\
\hline Organizations/youth services & & $0.006(0.021)$ & \\
\hline Natural log violent crime rate, 1993 & & & $0.085(0.030)^{* *}$ \\
\hline
\end{tabular}


Table 3. Reporting Intentions Regressed on Neighborhood Context, Demographic Variables, and Attitudes and Experiences $(N=1,354)$, Multilevel Ordered Logistic Regressing Using a Random Intercept Model

\begin{tabular}{|c|c|c|c|c|c|c|}
\hline \multirow[b]{2}{*}{ Variables } & \multicolumn{2}{|c|}{ Model 1 ${ }^{\mathrm{a}}$} & \multicolumn{2}{|c|}{ Model 2a } & \multicolumn{2}{|c|}{ Model $3^{\mathrm{a}}$} \\
\hline & $b$ & SE & $b$ & SE & $b$ & SE \\
\hline \multicolumn{7}{|l|}{ Neighborhood context } \\
\hline Poverty & $-.053 *$ & $(.025)$ & $-.050 *$ & $(.025)$ & -.038 & $(.026)$ \\
\hline $\begin{array}{l}\text { Latino/immigrant } \\
\text { concentration }\end{array}$ & .091 & (.061) & .093 & $(.062)$ & .056 & $(.064)$ \\
\hline Percent Black & -.008 & $(.005)$ & -.005 & $(.005)$ & -.006 & $(.006)$ \\
\hline Mobility & .001 & $(.006)$ & .001 & $(.006)$ & .000 & $(.006)$ \\
\hline \multicolumn{7}{|l|}{ Demographic variables } \\
\hline Black & & & $-.443^{*}$ & $(.207)$ & $-.441 *$ & $(.210)$ \\
\hline Latino & & & $-.355^{*}$ & $(.155)$ & -.195 & $(.160)$ \\
\hline Other race & & & -.139 & (.179) & -.078 & (.185) \\
\hline Female & & & $.399^{* *}$ & $(.100)$ & $.245^{*}$ & (.105) \\
\hline Age & & & $-.338^{* *}$ & $(.085)$ & $-.213 *$ & $(.088)$ \\
\hline Single-parent household & & & -.139 & (.133) & -.085 & (.136) \\
\hline $\begin{array}{l}\text { Parental education-less } \\
\text { than high school }\end{array}$ & & & -.332 & (.180) & -.314 & (.186) \\
\hline $\begin{array}{l}\text { Parental education- } \\
\text { post-high-school } \\
\text { education }\end{array}$ & & & -.037 & $(.118)$ & -.117 & $(.120)$ \\
\hline \multicolumn{7}{|l|}{$\begin{array}{l}\text { Experiences, attitudes, and } \\
\text { perceptions }\end{array}$} \\
\hline Treatment by police & & & & & & \\
\hline $\begin{array}{l}\text { Stopped or arrested } \\
\text { and satisfied }\end{array}$ & & & & & .376 & $(.235)$ \\
\hline $\begin{array}{l}\text { Stopped or arrested } \\
\text { and neither satisfied } \\
\text { nor dissatisfied }\end{array}$ & & & & & .070 & (.199) \\
\hline $\begin{array}{l}\text { Stopped or arrested } \\
\text { and dissatisfied }\end{array}$ & & & & & -.184 & $(.209)$ \\
\hline $\begin{array}{l}\text { Positive attitudes toward } \\
\text { the police }\end{array}$ & & & & & $.331^{* * *}$ & $(.072)$ \\
\hline Delinquency & & & & & $-.082 * *$ & $(.025)$ \\
\hline $\begin{array}{l}\text { Likelihood of } \\
\text { victimization }\end{array}$ & & & & & $.325^{* * *}$ & $(.059)$ \\
\hline $\begin{array}{l}\text { Perceptions of } \\
\text { community disorder }\end{array}$ & & & & & -.210 & $(.118)$ \\
\hline $\begin{array}{l}\text { Role of youth in the } \\
\text { community }\end{array}$ & & & & & $.508^{* * *}$ & (.097) \\
\hline Awareness of services & & & & & $.384^{* * * *}$ & (.079) \\
\hline
\end{tabular}


Table 2. Hierarchical Logistic Regression Models of Female Victimization by Intimate Partner Violence in 40 MSAs, 1989-2004 $(N=487,166)$

\begin{tabular}{|c|c|c|c|c|c|c|c|c|}
\hline \multirow[b]{2}{*}{ Variables } & \multicolumn{2}{|c|}{ Model 1} & \multicolumn{2}{|c|}{ Model 2} & \multicolumn{2}{|c|}{ Model 3} & \multicolumn{2}{|c|}{ Model 4} \\
\hline & Coefficient & (SE) & Coefficient & (SE) & Coefficient & (SE) & Coefficient & (SE) \\
\hline \multicolumn{9}{|l|}{ Police and Social Services (lagged 1 year) } \\
\hline Police force size (per 1,000 population) & $-.322^{* * *}$ & $(.079)$ & & & & & $-.261^{* * *}$ & $(.078)$ \\
\hline $\begin{array}{l}\text { Mandatory arrest laws (\% population governed by } \\
\text { the laws) }\end{array}$ & & & -.001 & $(.001)$ & & & .000 & $(.001)$ \\
\hline $\begin{array}{l}\text { Individual and family social services (per } 1,000 \\
\text { population) }\end{array}$ & & & & & $-.197^{* * *}$ & $(.054)$ & $-.143^{* *}$ & $(.053)$ \\
\hline \multicolumn{9}{|l|}{ Control Variables } \\
\hline \multicolumn{9}{|l|}{ Other MSA Characteristics (lagged 1 year) } \\
\hline Female labor force participation & -.013 & $(.019)$ & .004 & $(.018)$ & -.001 & $(.018)$ & -.013 & $(.018)$ \\
\hline Female-male differential in labor force participation & $.052^{*}$ & $(.024)$ & $.015^{*}$ & $(.007)$ & $.046^{*}$ & $(.022)$ & $.069^{*}$ & $(.032)$ \\
\hline Female income-educational attainment & $-.088^{* *}$ & $(.030)$ & $-.258^{* *}$ & $(.086)$ & $-.018^{*}$ & $(.008)$ & $-.046^{* *}$ & $(.016)$ \\
\hline $\begin{array}{l}\text { Female-male differential in income-educational } \\
\text { attainment }\end{array}$ & $-.950^{* * *}$ & $(.153)$ & $-.810^{* * *}$ & $(.167)$ & $-.705^{* * *}$ & $(.173)$ & $-.862^{* * *}$ & $(.165)$ \\
\hline Log population & .005 & $(.070)$ & .015 & $(.075)$ & .014 & $(.076)$ & .018 & $(.075)$ \\
\hline Percent population $15-29$ years of age & $.068^{*}$ & $(.032)$ & $.059^{*}$ & $(.029)$ & $.037^{*}$ & $(.016)$ & $.051^{*}$ & $(.024)$ \\
\hline Percent divorced/separated & $.148^{* * *}$ & $(.033)$ & $.181^{* * *}$ & $(.033)$ & $.116^{* * *}$ & $(.035)$ & $.114^{* * *}$ & $(.032)$ \\
\hline Socioeconomic disadvantage (a 6-variable scale) & .033 & $(.146)$ & .006 & $(.156)$ & .095 & $(.154)$ & .193 & $(.152)$ \\
\hline Percent Black & -.001 & $(.008)$ & -.011 & $(.007)$ & -.023 & $(.027)$ & -.011 & $(.009)$ \\
\hline $\begin{array}{l}\text { Immigrant concentration (\% Hispanic and \% } \\
\text { foreign-born) }\end{array}$ & .013 & $(.086)$ & -.029 & $(.089)$ & -.112 & $(.078)$ & -.077 & $(.088)$ \\
\hline
\end{tabular}


Table 2. Continued

\begin{tabular}{|c|c|c|c|c|c|c|c|c|}
\hline \multirow[b]{2}{*}{ Variables } & \multicolumn{2}{|c|}{ Model 1} & \multicolumn{2}{|c|}{ Model 2} & \multicolumn{2}{|c|}{ Model 3} & \multicolumn{2}{|c|}{ Model 4} \\
\hline & Coefficient & (SE) & Coefficient & (SE) & Coefficient & (SE) & Coefficient & (SE) \\
\hline \multicolumn{9}{|l|}{ Individual Characteristics } \\
\hline Age & $-.335^{* * *}$ & $(.019)$ & $-.335^{* * *}$ & $(.019)$ & $-.334^{* * *}$ & $(.019)$ & $-.334 * * *$ & $(.019)$ \\
\hline Household income & $-.222^{* * *}$ & $(.022)$ & $-.221^{* * *}$ & $(.022)$ & $-.222^{* * *}$ & $(.023)$ & $-.222^{* * *}$ & $(.023)$ \\
\hline Homeowner & $-.394^{* * *}$ & $(.082)$ & $-.394^{* * *}$ & $(.082)$ & $-.395^{* * *}$ & $(.083)$ & $-.396^{* * *}$ & $(.082)$ \\
\hline Divorced & $1.645^{* * *}$ & $(.106)$ & $1.645^{* * *}$ & $(.106)$ & $1.644^{* * *}$ & $(.107)$ & $1.643^{* * *}$ & $(.106)$ \\
\hline Separated & $2.677^{* * *}$ & $(.136)$ & $2.674^{* * *}$ & $(.136)$ & $2.673^{* * *}$ & $(.136)$ & $2.676^{* * *}$ & $(.136)$ \\
\hline Never married & $.475^{* * *}$ & $(.119)$ & $.475^{* * *}$ & $(.120)$ & $.478^{* * *}$ & $(.120)$ & $.478^{* * *}$ & $(.120)$ \\
\hline Widowed & -.399 & $(.249)$ & -.406 & $(.250)$ & -.406 & $(.250)$ & -.401 & $(.250)$ \\
\hline Black & -.124 & $(.091)$ & -.128 & $(.090)$ & -.127 & $(.090)$ & -.126 & $(.090)$ \\
\hline Hispanic & $-.554^{* * *}$ & $(.108)$ & $-.555^{* * *}$ & (.107) & $-.560^{* * *}$ & $(.106)$ & $-.560^{* * *}$ & $(.107)$ \\
\hline Other race & $-.926^{* * *}$ & $(.234)$ & $-.907^{* * *}$ & $(.236)$ & $-.910^{* * *}$ & $(.237)$ & $-.929^{* * *}$ & $(.233)$ \\
\hline Year of interview & $.143^{* *}$ & $(.051)$ & $.148^{* *}$ & $(.057)$ & $.134^{*}$ & $(.054)$ & $.133^{* *}$ & $(.048)$ \\
\hline Year squared & $-.008^{* *}$ & $(.003)$ & $-.008^{* *}$ & $(.003)$ & $-.006^{*}$ & $(.003)$ & $-.006^{*}$ & $(.003)$ \\
\hline NCVS redesign & .225 & $(.148)$ & .215 & $(.151)$ & .193 & $(.152)$ & .207 & $(.150)$ \\
\hline \multirow[t]{2}{*}{ Intercept, $\pi_{000}$} & $-7.432^{* * *}$ & $(.189)$ & $-7.446^{* * *}$ & $(.219)$ & $-7.472^{* * *}$ & $(.200)$ & $-7.452^{* * *}$ & $(.180)$ \\
\hline & Variance & $\chi^{2}$ & Variance & $\chi^{2}$ & Variance & $\chi^{2}$ & Variance & $\chi^{2}$ \\
\hline Level-2 random effect & $.098^{* * *}$ & 744.457 & $.123^{* * *}$ & 738.103 & $.120^{* * *}$ & 737.580 & $.082^{*}$ & 660.646 \\
\hline Level-3 random effect & $.002^{*}$ & 60.126 & $.027^{* *}$ & 64.880 & $.007^{*}$ & 60.372 & $.001^{*}$ & 58.021 \\
\hline-2 (log-likelihood) & & 910158.438 & & 910225.243 & & 910226.974 & & 910143.642 \\
\hline LR $\chi^{2}$ versus & & $226159.002^{* * *}$ & & $226092.197^{* * *}$ & & $226090.466^{* * *}$ & & $226173.798^{* * *}$ \\
\hline $\begin{array}{l}\text { unconditional model } \\
\text { (d.f.) }\end{array}$ & & (24) & & $(24)$ & & (24) & & (26) \\
\hline
\end{tabular}

